\title{
Zeolitová mineralizace z Libé u Chebu (Česká republika)
}

\author{
Zeolite mineralization from Libá near Cheb (Czech Republic)
}

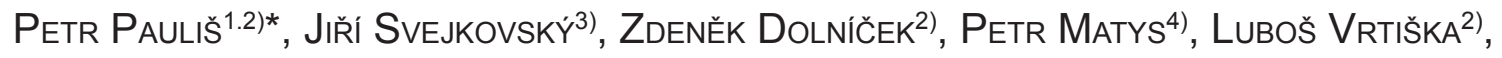 \\ Radana Malíkováa a OndŘej Pour ${ }^{5)}$ \\ 1)Smíškova 564, 28401 Kutná Hora; *e-mail: petr.paulis@post.cz \\ 2) Mineralogicko-petrologické oddělení, Národní muzeum, Cirkusová 1740, 19300 Praha 9 - Horní Počernice \\ 3) Severočeské doly a. s. - doly Bílina, Důlní 375/89, 41829 Bílina \\ 4) Technický a zkušební ústav stavební Praha, s. p., Tolstého 447, 41503 Teplice \\ 5) Česká geologická služba, Geologická 6, 15200 Praha 5
}

Pauliš P, Svejkovský J, Dolníček Z, Matys P, VRtiška L, Malíková R, Pour O (2020) Zeolitová mineralizace z Libé u Chebu (Česká republika). Bull Mineral Petrolog 28(1): 152-160 ISSN 2570-7337

\begin{abstract}
A new occurrence of zeolite mineralization with phillipsite-K, phillipsite-Ca, thomsonite-Ca, natrolite and gonnardite has been discovered in an active basalt quarry in the Libá village near Cheb (Czech Republic). Phillipsites form druses of white or colourless crystals up to $1 \mathrm{~mm}$ in size in small cavities. Chemical analyses of phillipsite-K correspond to the empirical formula $\left(\mathrm{K}_{1.85} \mathrm{Na}_{1.24} \mathrm{Ca}_{0.83} \mathrm{Ba}_{0.27} \mathrm{Sr}_{0.01}\right)_{\Sigma 4.20}\left(\mathrm{Al}_{6.28} \mathrm{Si}_{10.33} \mathrm{O}_{32}\right) \cdot 12 \mathrm{H}_{2} \mathrm{O}$ and phillipsite-Ca to $\left(\mathrm{Ca}_{1.84} \mathrm{~K}_{1.33} \mathrm{Na}_{0.14} \mathrm{Ba}_{0.06}\right)_{\Sigma 3.37}\left(\mathrm{Al}_{5.97} \mathrm{Si}_{10.20} \mathrm{O}_{32}\right)$ - $12 \mathrm{H}_{2} \mathrm{O}$. The unit-cell parameters were refined from the powder X-ray data for phillipsite-Ca as: a 9.924(2), b 14.309(3), $c$ 8.7414(14) $\AA, \beta$ 124.92(2) ${ }^{\circ}$ and $V$ 1017.8(5) $\AA^{3}$. Thomsonite-Ca forms transparent hemispheric radial aggregates up to $1 \mathrm{~cm}$ in size. Its unit-cell parameters refined from the powder X-ray data are a 13.105(5), $b$ 13.857(5), c 13.247(6) $\AA$ and $V$ 2266.7(6) $\AA^{3}$ and its chemical analyses correspond to the empirical formula $\mathrm{Ca}_{1.79} \mathrm{Sr}_{0.18} \mathrm{Na}_{1.05}\left(\mathrm{Al}_{4.81} \mathrm{Si}_{5.15}\right) \mathrm{O}_{20} \cdot 6 \mathrm{H}_{2} \mathrm{O}$. Natrolite occurs as snow white hemispheric radial clusters. Its unit-cell parameters refined from the powder $\mathrm{X}$-ray data are a 18.326(7), b 18.569(7), c 6.594(3) $\AA$ and $V$ 2243.8(9) $\AA^{3}$ and empirical formula is $\mathrm{Na}_{1.60} \mathrm{Ca}_{0.05}\left(\mathrm{Al}_{2.08} \mathrm{Si}_{3.02}\right) \mathrm{O}_{10} \cdot 2 \mathrm{H}_{2} \mathrm{O}$. Gonnardite forms colourless or white aggregates of flat acicular crystals up to $2 \mathrm{~mm}$ in size. Its unit-cell parameters refined from the powder $X$-ray data are a 13.221(8), c 6.6233(4) $\AA$ and $V 1156.9 \AA^{3}$ and empirical formula is $\left(\mathrm{Na}_{3.14} \mathrm{Ca}_{2.21}\right.$ $\left.\mathrm{Sr}_{0.02}\right)_{\Sigma 5.37}\left(\mathrm{Al}_{8.92} \mathrm{Si}_{11.41}\right)_{\Sigma 20.33} \mathrm{O}_{40} \cdot 12 \mathrm{H}_{2} \mathrm{O}$.
\end{abstract}

Key words: phillipsite-K, phillipsite-Ca, thomsonite-Ca, natrolite, gonnardite, powder X-ray diffraction data, unit-cell parameters, chemical composition, Libá near Cheb, Czech Republic

Obdrženo 4. 5. 2020; prijjato 5. 6. 2020

\section{Úvod}

Kamenolom se studovanou mineralizací se nachází jz. od obce Libá (dř. Libštejn, něm. Liebenstein), 11 km sz. od Chebu na j. svahu vrchu Blatná (dř́ve Vysoká, něm. Hohenberg) $641 \mathrm{~m} \mathrm{n}$. m., zhruba $1 \mathrm{~km}$ od hranice s Německem (GPS: $50^{\circ} 7$ ‘'14.1'N,12¹3‘24.1“E). Byl založen již před rokem 1945, v letech 1945 - 1951 tu probíhala těžba kameniva $v$ rámci krajského výrobního podniku se sídlem v Chebu. Počínaje rokem 1951 byla těžba rozšiřena pro potřeby stavby nedalekého vodního díla Jesenice. V letech 1957 - 1959 tu probíhal geologický průzkum ukončený výpočtem zásob (Čtyřoký, Koubek 1959). V současnosti je kamenolom ve vlastnictví firmy Basalt CZ s.r.o., vyrábějící drcené kamenivo. Ložisko má tvar plochého čedičového výlevu o mocnosti cca $40 \mathrm{~m}$. Minimální báze výpočtu je $570 \mathrm{~m} \mathrm{n}$. m., pod touto úrovní nejsou zásoby vyhodnoceny. Plocha ložiska je 275 tisíc $\mathrm{m}^{2}(700 \times 270 \mathrm{~m})($ Hrzina et al. 2016).

\section{Geologie a petrologie lokality}

Lokalitu zeolitů představuje činný kamenolom (obr. 1) založený $v$ terciérním výlevu olivinického nefelinitu, který je nejzápadnějším vulkanickým tělesem tzv. ohá- reckého riftu na našem území. Vulkanit proniká horninami smrčinského žulového masivu, který též tvoří podloží čedičového tělesa. Smrčinský žulový masiv je protínán několika tektonickými liniemi; hlavní uplatnění má směr SZ - JV. Tektonické zóny tohoto směru jsou v širším okolí často vyplněny žilným křemenem (tzv. ašský křemenný val) nebo bazickými vulkanity či lamprofyry. Čediče většinou nasedají přímo na podložní granity, lokálně je při bázi ložiskových poloh vyvinuta 1 - $5 \mathrm{~m}$ mocná poloha tufového konglomerátu, v jednom vrtu byla na bázi čediče zastižena poloha kaolinizovaného pískovce a slepence. $\checkmark$ nadloží bazaltů, $v$ jeho depresích, byly na vrcholové plošině uchovány denudační zbytky tufových poloh až 10 $\mathrm{m}$ mocné. Kvartér je v okolí zastoupen především aluvii recentních toků, svahovými hlínami a hlinitokamenitými sutěmi (Hrzina et al. 2016).

Bazaltické horniny tvoři morfologicky výrazný plochý vrch s výraznější elevací na severu a na jižním okraji plošiny. Jde patrně o zbytek původně rozsáhlejšího vulkanického tělesa s poměrně složitou stavbou, ve kterém se vedle převládajících výlevných hornin podstatně uplatňují i horniny vulkanoklastické. Těženou horninou je olivinický nefelinit. Jde o černošedou porfyrickou masivní hor- 
ninu, která je v rámci ložiska petrologicky homogenní. Je tvořena velmi jemnozrnnou základní hmotou tvořenou augitem, nefelinem a Ti-bohatým magnetitem. V základní hmotě lze makroskopicky rozeznat až $3 \mathrm{~mm}$ velké vyrostlice olivínu a augitu. Strukturu horniny Ize označit jako drobně porfyrickou s holomikrokrystalickou strukturou základní hmoty (Hrzina et al. 2016).

Charakteristickým rysem zdejších nefelinitů je jejich sloupcovitá odlučnost (obr. 2). Sloupce mají většinou vertikální orientaci, ve východní části jsou uspořádané vějiřrovitě. Velikost sloupců je proměnlivá, jejich šírka se pohy- rakčních maxim byly popsány profilovou funkcí Pseudo -Voigt a upřesněny profilovým fitováním v programu HighScore Plus. Mřižkové parametry byly zpřesněny metodou nejmenších čtverců pomocí programu Celref (Laugier, Bochu 2011).

Chemické složení zeolitů bylo kvantitativně stanoveno pomocí elektronového mikroanalyzátoru Cameca SX100 (Národní muzeum. Praha) za podmínek: vlnově disperzní analýza, napětí $15 \mathrm{kV}$, proud $5 \mathrm{nA}$, průměr svazku 5 $\mu \mathrm{m}$, standardy: baryt (BaL $\alpha)$, albit (NaKa), sanidin (SiKa,

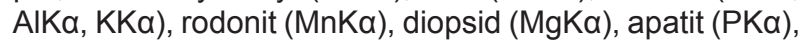

buje v rozmezí 0.2 - $1.5 \mathrm{~m}$, maximální rozměry mají sloupce na severním okraji ložiska. Z jejich rozměrů Ize usuzovat na blízkost centrální části vulkanického tělesa, v níž docházelo k pomalejšímu tuhnutí. Navětrání čediče Ize pozorovat do hloubky 10 - 15 $\mathrm{m}$. Projevuje se větším rozpukáním svrchních partií, limonitovými záteky podél trhlin a zvětráním vyrostlic olivínu. Dnes již odtěžené pyroklastické horniny tvořily kapsovité polohy ve vrcholové části plošiny o mocnosti do $10 \mathrm{~m}$. Většinově šlo o velmi měkké, šedé až hnědé lapillové tufy (Krutský 2019).

\section{Metodika výzkumu}

Rentgenová prášková difrakční data byla získána pomocí práškového difraktometru Bruker D8 Advance (Národní muzeum, Praha) s polovodičovým pozičně citlivým detektorem LynxEye za užití CuKa záření (40 kV, $40 \mathrm{~mA}$ ). Práškové preparáty byly naneseny $v$ acetonové suspenzi na nosič zhotovený z monokrystalu křemíku a následně pak byla pořízena difrakční data ve step-scanning režimu (krok $0.01^{\circ}$, načítací čas $8 \mathrm{~s} / \mathrm{krok}$ detektoru, celkový čas experimentu cca 15 hod.). Pozice jednotlivých dif-

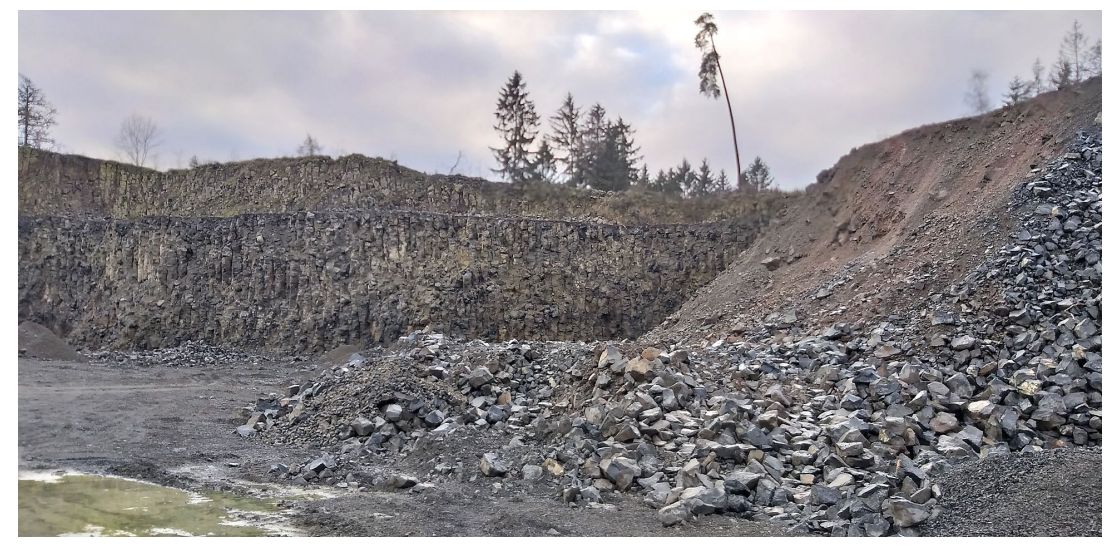

Obr. 1 Kamenolom Libá u Chebu, jižní část, foto P. Matys, 2019.

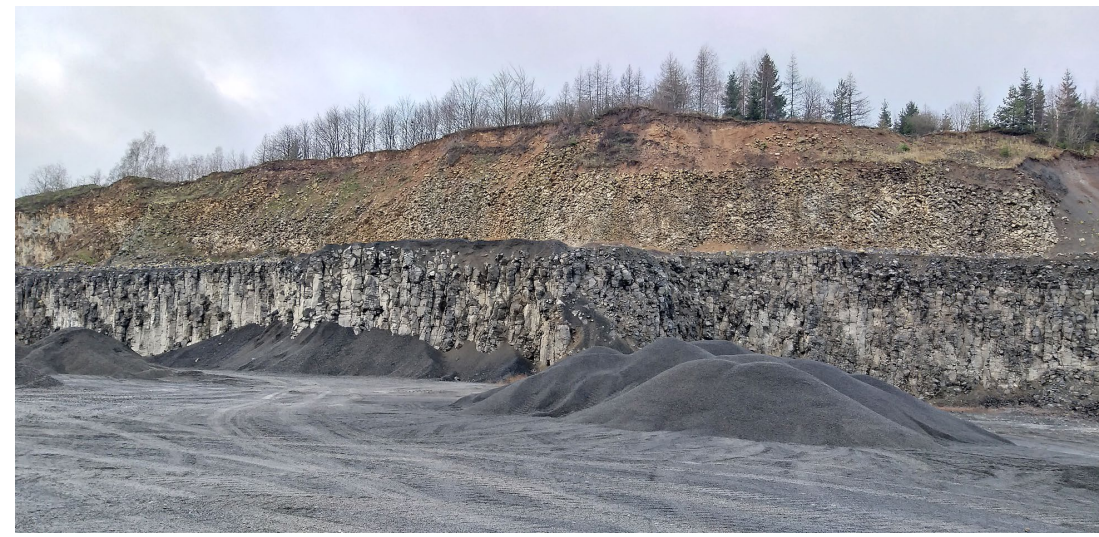

Obr. 2 Střední část kamenolomu Libá u Chebu, která je tvořena nefelinitovými sloupci, foto P. Matys, 2019.

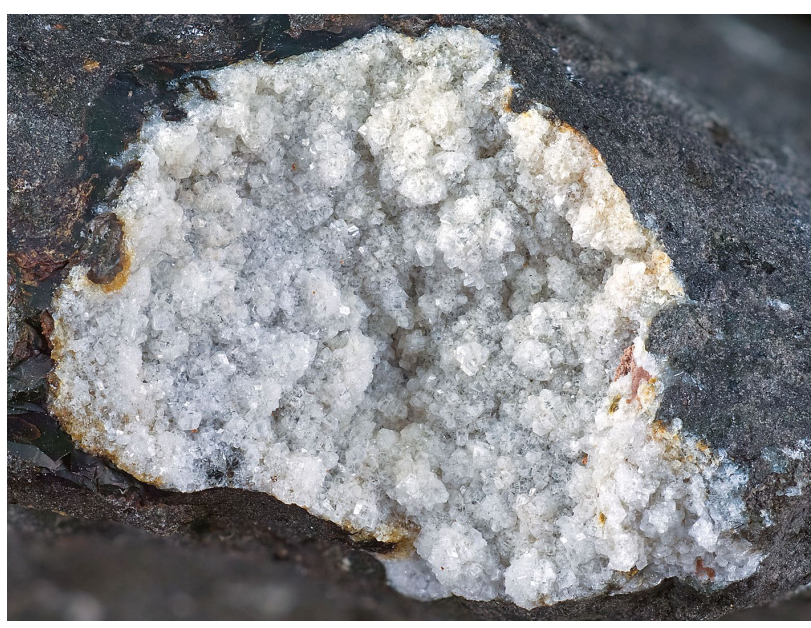

Obr. 3 Dutina $v$ bazaltu vyplněná krystaly phillipsitu z Libé, šírka záběru 20 mm, foto P. Fuchs.

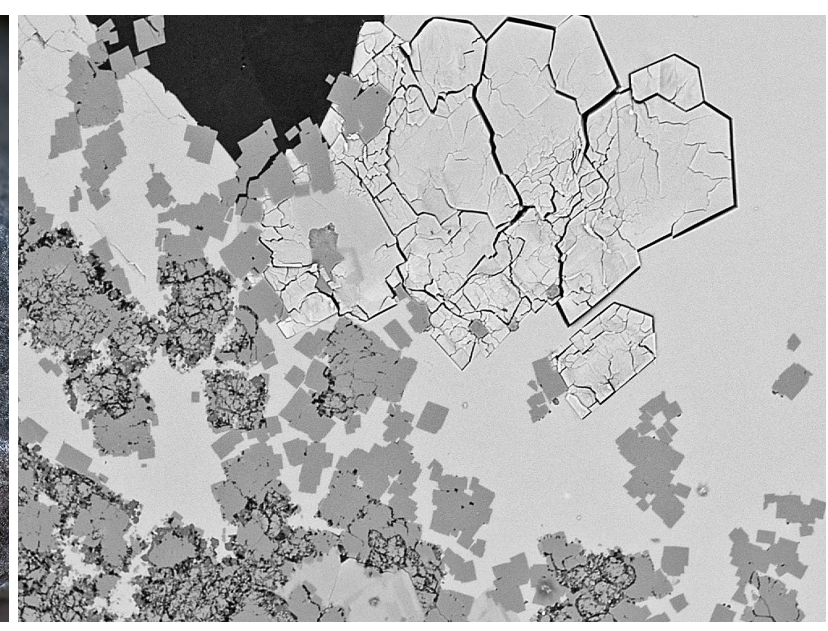

Obr. 4 Kalcit (světlý) s obdélníkovými průřezy krystalů natrolitu (šedý) a krystaly phillipsitu-Ca (světlý v pravé části snímku). Šiřka záběru $0.72 \mathrm{~mm}$. BSE foto Z. Dolníček. 
hematit (FeKa), ZnO (ZnKa), celestin (SKa, SrLa), Cs sklo (CsKa), wollastonit (CaKa) a topaz (FKa). Obsahy $\mathrm{Cs}, \mathrm{Fe}, \mathrm{Mg}, \mathrm{Mn}, \mathrm{P}, \mathrm{S}, \mathrm{Zn}$ a F byly pod mezí detekce prístroje (cca $0.03-0.05 \mathrm{hm}$. \%). Získaná data byla korigována za použití software PAP (Pouchou, Pichoir 1985).

\section{Charakterizace zjištěné mineralizace}

Mineralogií nefelinitů od Libé se jako jediný zabýval Koster (1886) in Kratochvíl (1961), který z čedičů mezi Libou a Hohenbergem $\vee$ Bavorsku popsal krystaly harmotomu (správně phillipsitu), stilbit či heulandit, zaoblené krystaly a zrna čedičového amfibolu z čedičových pum a hyalit. $V$ novější době nikdo mineralogii zdejší zeolitové mineralizace nestudoval.
Zeolitová mineralizace byla nalezena jedním z autorů (PM) na puklinách a $v$ drobných dutinách nefelinitu $v$ srpnu 2019. V rámci pracovní návštěvy spojené s odběrem vzorků pro laboratorní zkoušky kameniva tu byly na spodním patře $v$ částečně odtěženém odstřelu ve střední části kamenolomu nalezeny nehojné zeolitové výplně puklin a dutin. Při opakované návštěvě lomu v záři 2019 byly v odstřelu a deponii kameniva v jižní části lomu objeveny další vzorky zeolitové mineralizace.

\section{Phillipsit-K a phillipsit-Ca}

Nejstarším zeolitem studované mineralizace je phillipsit, který narůstá na stěny puklin a až $10 \mathrm{~cm}$ velkých plochých dutin v nefelinitu ve formě jemné bílé kưry tvo-

Tabulka 1 Rentgenová prášková data phillipsitu-Ca z Libé

\begin{tabular}{|c|c|c|c|c|c|c|c|c|c|c|c|c|c|c|c|c|c|}
\hline$h$ & $k$ & I & $d_{o b s}$ & $I_{o b s}$ & $d_{\text {calc }}$ & $h$ & $k$ & 1 & $d_{o b s}$ & $I_{o b s}$ & $d_{\text {calc }}$ & $h$ & $k$ & 1 & $d_{o b s}$ & $I_{o b s}$ & $d_{\text {calc }}$ \\
\hline-1 & 0 & 0 & 8.130 & 2 & 8.137 & -2 & 6 & 1 & 2.1496 & 1 & 2.1495 & -3 & 7 & 3 & 1.6356 & 2 & 1.6357 \\
\hline-1 & 1 & 1 & 7.111 & 73 & 7.103 & 2 & 1 & 2 & 2.1260 & $<1$ & 2.1239 & -6 & 0 & 2 & 1.6083 & 1 & 1.6095 \\
\hline 0 & 1 & 1 & 6.368 & 18 & 6.408 & -3 & 2 & 4 & 2.0783 & 1 & 2.0790 & -6 & 1 & 2 & 1.5993 & 1 & 1.5994 \\
\hline 1 & 2 & 0 & 5.346 & 13 & 5.373 & -2 & 6 & 2 & 2.0621 & $<1$ & 2.0603 & -5 & 2 & 5 & 1.5942 & 2 & 1.5952 \\
\hline 0 & 2 & 1 & 5.033 & 22 & 5.064 & 2 & 2 & 2 & 2.0565 & $<1$ & 2.0570 & -2 & 3 & 5 & 1.5905 & $<1$ & 1.5917 \\
\hline-2 & 0 & 1 & 4.919 & 11 & 4.962 & -2 & 5 & 3 & 2.0408 & 1 & 2.0416 & 2 & 3 & 3 & 1.5863 & $<1$ & 1.5864 \\
\hline 1 & 0 & 1 & 4.299 & 4 & 4.295 & 4 & 0 & 0 & 2.0343 & 1 & 2.0343 & -3 & 4 & 5 & 1.5678 & $<1$ & 1.5689 \\
\hline 1 & 3 & 0 & 4.117 & 16 & 4.115 & -3 & 5 & 3 & 1.9743 & 3 & 1.9743 & -6 & 3 & 3 & 1.5632 & $<1$ & 1.5627 \\
\hline-2 & 0 & 2 & 4.090 & 24 & 4.091 & 2 & 3 & 2 & 1.9584 & 2 & 1.9583 & -5 & 5 & 4 & 1.5464 & 2 & 1.5458 \\
\hline-2 & 1 & 2 & 3.947 & 3 & 3.933 & -5 & 1 & 2 & 1.9470 & $<1$ & 1.9462 & 1 & 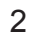 & 4 & 1.5354 & 1 & 1.5346 \\
\hline 2 & 1 & 0 & 3.913 & 2 & 3.913 & -1 & 2 & 4 & 1.9353 & $<1$ & 1.9332 & -5 & - & 2 & 1.5162 & $<1$ & 1.5163 \\
\hline 1 & 2 & 1 & 3.680 & 1 & 3.683 & -2 & 7 & 1 & 1.8876 & $<1$ & 1.8900 & -1 & 3 & 5 & 1.4946 & $<1$ & 1.4948 \\
\hline 2 & 2 & 0 & 3.531 & 1 & 3.537 & -2 & 7 & 2 & 1.8292 & 3 & 1.8286 & 1 & 9 & 1 & 1.4912 & $<1$ & 1.4910 \\
\hline 0 & 1 & 2 & 3.466 & 3 & 3.476 & 2 & 7 & 0 & 1.8246 & 1 & 1.8266 & 3 & 7 & 1 & 1.4854 & 2 & 1.4848 \\
\hline 1 & 3 & 1 & 3.183 & 100 & 3.192 & 1 & 0 & 2 & 1.7990 & $<1$ & 1.8017 & -6 & 4 & 2 & 1.4682 & $<1$ & 1.4678 \\
\hline-3 & 1 & 1 & 3.131 & 14 & 3.141 & -3 & 6 & 3 & 1.7946 & $<1$ & 1.7953 & -4 & 8 & 2 & 1.4512 & $<1$ & 1.4509 \\
\hline-3 & 2 & 1 & 2.927 & 5 & 2.936 & 0 & 8 & 0 & 1.7884 & 4 & 1.7886 & 1 & 4 & 4 & 1.4393 & 1 & 1.4386 \\
\hline-2 & 1 & 3 & 2.854 & $<1$ & 2.855 & 0 & 1 & 4 & 1.7775 & 2 & 1.7780 & -6 & 3 & 5 & 1.4353 & 1 & 1.4353 \\
\hline-1 & 4 & 2 & 2.753 & 10 & 2.754 & -4 & 4 & 4 & 1.7750 & 1 & 1.7757 & -3 & 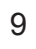 & 1 & 1.4260 & 1 & 1.4255 \\
\hline-1 & 5 & 1 & 2.703 & 10 & 2.701 & 4 & 4 & 0 & 1.7694 & 2 & 1.7683 & -4 & 8 & 3 & 1.4236 & 1 & 1.4230 \\
\hline 2 & 4 & 0 & 2.689 & 18 & 2.686 & 0 & 8 & 1 & 1.7347 & $<1$ & 1.7354 & 5 & 5 & 0 & 1.4146 & $<1$ & 1.4147 \\
\hline 3 & 1 & 0 & 2.666 & 4 & 2.665 & -2 & 5 & 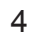 & 1.7234 & 1 & 1.7228 & -6 & 5 & 2 & 1.4030 & 1 & 1.4029 \\
\hline 1 & 2 & 2 & 2.5690 & 1 & 2.5669 & 2 & 5 & 2 & 1.7181 & 2 & 1.7178 & 2 & 9 & 1 & 1.3941 & $<1$ & 1.3938 \\
\hline 3 & 2 & 0 & 2.5375 & 1 & 2.5362 & -4 & 1 & 5 & 1.7129 & $<1$ & 1.7135 & -7 & 2 & 3 & 1.3834 & $<1$ & 1.3834 \\
\hline 1 & 3 & 2 & 2.3833 & 4 & 2.3824 & -5 & 3 & 1 & 1.7071 & 1 & 1.7078 & 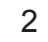 & 0 & 4 & 1.3750 & 1 & 1.3750 \\
\hline-4 & 0 & 3 & 2.3510 & $<1$ & 2.3487 & -2 & 8 & 1 & 1.6828 & 2 & 1.6826 & -5 & 3 & 6 & 1.3694 & 2 & 1.3692 \\
\hline-4 & 1 & 1 & 2.3080 & $<1$ & 2.3095 & -4 & 2 & 5 & 1.6784 & 2 & 1.6778 & -5 & . & 4 & 1.3666 & $<1$ & 1.3662 \\
\hline 2 & 4 & 1 & 2.2532 & 2 & 2.2514 & -2 & 7 & 3 & 1.6733 & 1 & 1.6733 & 5 & 3 & 1 & 1.3621 & $<1$ & 1.3619 \\
\hline-4 & 2 & 1 & 2.2250 & 2 & 2.2242 & -1 & 5 & 4 & 1.6439 & 1 & 1.6437 & -7 & 3 & 3 & 1.3528 & $<1$ & 1.3521 \\
\hline-3 & 4 & 3 & 2.1712 & $<1$ & 2.1688 & 1 & 7 & 2 & 1.6403 & 2 & 1.6406 & -5 & 6 & 5 & 1.3495 & $<1$ & 1.3493 \\
\hline 3 & 0 & 1 & 2.1597 & 1 & 2.1602 & & & & & & & & & & & & \\
\hline
\end{tabular}

Tabulka 2 Parametry základní cely phillipsitu (pro monoklinickou prostorovou grupu $P 2, / m$ )

\begin{tabular}{llllllll}
\hline & & $a[\AA]$ & $b[\AA]$ & $c[\AA]$ & $\beta\left[^{\circ}\right]$ & $V\left[\AA^{3}\right]$ \\
\hline phillipsit-Ca & Libá u Chebu & tato práce & $9.924(2)$ & $14.309(3)$ & $8.7414(14)$ & $124.92(2)$ & $1017.8(5)$ \\
phillipsit-Ca & Poustevna & Pauliš et al. (2019) & $9.9206(19)$ & $14.315(3)$ & $8.7387(19)$ & $124.92(6$ & $1017.5(4)$ \\
phillipsit-Ca & Zaječí vrch & Pauliš et al. (2019) & $9.9226(19)$ & $14.314(3)$ & $8.7396(17)$ & $124.92(5)$ & $1017.8(4)$ \\
phillipsit-Ca & Heřmanice & Pauliš et al. (2018a) & $9.922(19)$ & $14.314(4)$ & $8.742(18)$ & $124.91(3)$ & $1018.0(4)$ \\
phillipsit-K & Svor & Pauliš et al. (2016b) & $9.924(2)$ & $14.315(3)$ & $8.742(2)$ & $124.93(7)$ & $1018.2(4)$ \\
phillipsit-K & Vrbička & Pauliš et al. (2013) & $9.919(3)$ & $14.314(3)$ & $8.740(3)$ & $124.93(1)$ & $1017.5(6)$ \\
phillipsit-K & Nový Oldřichov & Pauliš et al. (2016a) & $9.925(1)$ & $14.312(3)$ & $8.740(2)$ & $124.92(3)$ & $1018.0(3)$ \\
phillipsit-Ca & Nový Oldřichov Pauliš et al. (2016a) & $9.922(1)$ & $14.313(3)$ & $8.743(2)$ & $124.91(2)$ & $1018.1(3)$ \\
phillipsit & & Gatta et al. (2009) & $9.9238(6)$ & $14.3145(5)$ & $8.7416(5)$ & $124.920(9)$ & 1018.2 \\
\hline
\end{tabular}


řené drobnými krystaly (obr. 3), kde tvoří podložku mladším zeolitům či kalcitu (obr. 4). Vzácněji vytvárí v menších dutinách drúzy bílých až čirých, skelně lesklých, typicky rýhovaných, většinou zdvojčatělých krystalů o velikosti do $1 \mathrm{~mm}$.

Rentgenová prášková data získaná pro phillipsit-Ca (tab. 1) jsou blízká datům pro tento minerální druh, zpřesněné parametry jeho základní cely (tab. 2) dobře odpovídají publikovaným údajům pro tento zeolit.

Při studiu chemického složení byly na lokalitě rozlišeny dva druhy phillipsitu (phillipsit-Ca a phillipsit-K). Oba jsou v BSE obraze chemicky homogenní. Na složení phillipsitu-K (tab. 3) se podílejí $\mathrm{Si}, \mathrm{Al}, \mathrm{Ca}, \mathrm{Ba}, \mathrm{Sr}, \mathrm{Na}$ a $\mathrm{K}$; ostatní měřené prvky byly pod mezí detekce. Vedle dominantního obsahu K (1.85 apfu) obsahuje tento phillipsit poměrně velké obsahy $\mathrm{Na}(1.24 \mathrm{apfu})$ a $\mathrm{Ca}(0.83 \mathrm{apfu}) . \mathrm{Ob}-$ sah harmotomové složky je poměrně malý; obsah $\mathrm{Ba}$ dosahuje 0.27 $a p f u$. Vedle toho je $v$ kationtové části zastoupena malá príměs $\mathrm{Sr}(0.01$ $a p f u)$. Empirický vzorec phillipsitu-K (průměr pěti bodových analýz) je na bázi 32 kyslíků možno vyjádřit jako $\left(\mathrm{K}_{1.85} \mathrm{Na}_{1.24} \mathrm{Ca}_{0.83} \mathrm{Ba}_{0.27} \mathrm{Sr}_{0.01}\right)_{\Sigma 4.20}\left(\mathrm{Al}_{6.28}\right.$ $\left.\mathrm{Si}_{10.33} \mathrm{O}_{32}\right) \cdot 12 \mathrm{H}_{2} \mathrm{O}$. Hodnota $\mathrm{T}_{\mathrm{Si}}=\mathrm{Si} /$ $(\mathrm{Si}+\mathrm{Al})=0.62$ phillipsitu-K $\mathrm{K}^{\mathrm{Si}}$ je př̀ spodní hranici rozmezí uváděného pro tento zeolit (0.59-0.76) (Coombs et al. 1997).

Při studiu chemického složení phillipsitu-Ca (tab. 4) byly zjištěny obsahy $\mathrm{Si}, \mathrm{Al}, \mathrm{Ca}, \mathrm{Ba}, \mathrm{Na}$ a $\mathrm{K}$; ostatní měřené prvky byly pod mezí detekce. Vedle dominantního obsahu $\mathrm{Ca}$ (1.84 apfu) obsahuje tento phillipsit 1.33 apfu $\mathrm{K}$ a malé príměsi $\mathrm{Na}$ a Ba. Empirický vzorec phillipsitu-Ca (průměr šesti bodových analýz) je na bázi 32 kyslíků možno vyjádřit jako $\left(\mathrm{Ca}_{1.84} \mathrm{~K}_{1.33} \mathrm{Na}_{0.14} \mathrm{Ba}_{0.06}\right)_{\Sigma 3.37}\left(\mathrm{Al}_{5.97}\right.$ $\left.\mathrm{Si}_{10.20} \mathrm{O}_{32}\right) \cdot 12 \mathrm{H}_{2} \mathrm{O}$. Hodnota $\mathrm{T}_{\mathrm{Si}}=\mathrm{Si} /$ $(\mathrm{Si}+\mathrm{Al})=0.63$ tohoto phillipsitu se nachází ve spodní části předepsaného rozmezí pro tento zeolit $(0.57-0.74)$ (Coombs et al. 1997).

\section{Thomsonit-Ca}

Thomsonit-Ca byl nalezen pouze při první návštěvě lomu $v$ odstřelu $v$ jeho střední části. Tvoři čiré polokulovité, radiálně paprsčité agregáty složené z jednotlivých tence sloupečkovitých až pravítkovitých krystalů ukončených rovnou bází. Jednotlivé agregáty thomsonitu dosahuji průměru až $1 \mathrm{~cm}$ a narůstají na starší sněhově bílý paprsčitý natrolit. $V$ některých případech je natrolit vyloužen a polokulovité agregáty thomsonitu -Ca jsou duté (obr. 5). Velikost nepravidelných plochých dutin s thomsonitem dosahovala až $15 \times 7 \mathrm{~cm}$. Na thomsonit někdy narůstají drobné, nedokonale vyvinuté, šedobílé klen- cové krystaly kalcitu nebo je povlékán práškovitým jílovým minerálem žlutošedé barvy.

Rentgenová prášková data thomsonitu-Ca z Libé u Chebu (tab. 5) jsou blízká datům pro tento minerální druh, zpřesněné parametry základní cely (tab. 6) dobře odpovídají publikovaným údajům pro tento zeolit. V BSE obraze jsou krystaly thomsonitu-Ca chemicky homogenní. Při studiu jeho chemického složení (tab. 7) byly zjištěny obsahy $\mathrm{Si}, \mathrm{Al}, \mathrm{Ca}, \mathrm{Sr}$ a $\mathrm{Na}$; ostatní měřené prvky byly pod mezí detekce. Vedle dominantního obsahu $\mathrm{Ca}$ (1.79 apfu) a Na (1.05 apfu) obsahuje tento thomsonit malou príměs $\mathrm{Sr}(0.18 \mathrm{apfu})$. Zvýšené obsahy Sr jsou u thomsonitu poměrně časté; $v$ ČR byly vysoké koncent-

Tabulka 3 Chemické složení phillipsitu-K z Libé (hm. \%)

\begin{tabular}{lrrrrrr}
\hline & mean & 1 & 2 & 3 & 4 & 5 \\
\hline $\mathrm{SiO}_{2}$ & 44.13 & 43.19 & 43.53 & 43.44 & 45.20 & 45.29 \\
$\mathrm{Al}_{2} \mathrm{O}_{3}$ & 24.27 & 24.32 & 23.98 & 24.87 & 24.58 & 23.60 \\
$\mathrm{CaO}$ & 3.53 & 3.74 & 3.33 & 3.73 & 3.20 & 3.66 \\
$\mathrm{BaO}$ & 3.18 & 3.07 & 3.39 & 3.31 & 3.35 & 2.76 \\
$\mathrm{SrO}$ & 0.11 & 0.12 & 0.06 & 0.15 & 0.11 & 0.09 \\
$\mathrm{Na}_{2} \mathrm{O}$ & 2.92 & 3.24 & 3.65 & 2.86 & 2.33 & 2.54 \\
$\mathrm{~K}_{2} \mathrm{O}$ & 6.61 & 7.26 & 7.63 & 6.85 & 5.82 & 5.48 \\
$\mathrm{H}_{2} \mathrm{O}$ & 16.37 & 16.64 & 16.69 & 16.75 & 16.92 & 16.77 \\
\hline $\mathrm{total}^{2}$ & 101.12 & 101.58 & 102.26 & 101.96 & 101.51 & 100.19 \\
\hline $\mathrm{Si}^{4+}$ & 10.326 & 9.943 & 9.993 & 9.934 & 10.234 & 10.345 \\
$\mathrm{Al}^{3+}$ & 6.284 & 6.195 & 6.093 & 6.294 & 6.160 & 5.957 \\
$\mathrm{Ca}^{2+}$ & 0.832 & 0.866 & 0.764 & 0.858 & 0.729 & 0.838 \\
$\mathrm{Ba}^{2+}$ & 0.273 & 0.260 & 0.286 & 0.279 & 0.278 & 0.232 \\
$\mathrm{Sr}^{2+}$ & 0.014 & 0.014 & 0.008 & 0.018 & 0.014 & 0.012 \\
$\mathrm{Na}^{+}$ & 1.244 & 1.329 & 1.526 & 1.190 & 0.961 & 1.057 \\
$\mathrm{~K}^{+}$ & 1.853 & 2.000 & 2.098 & 1.876 & 1.579 & 1.500 \\
\hline$\Sigma \mathrm{Ca}+\mathrm{Ba}+\mathrm{Sr}+\mathrm{Na}+\mathrm{K}$ & 4.216 & 4.499 & 4.682 & 4.221 & 3.561 & 3.639 \\
\hline $\mathrm{H}_{2} \mathrm{O}$ & 12 & 12 & 12 & 12 & 12 & 12 \\
$\mathrm{~T}_{\mathrm{Si}}$ & 0.62 & 0.61 & 0.62 & 0.61 & 0.62 & 0.63 \\
\hline $\mathrm{Em}^{2+}$ & & & &
\end{tabular}

Empirický vzorec byl přepočten na bázi 32 kyslíků, $\mathrm{H}_{2} \mathrm{O}$ bylo dopočítáno na základě teoretického obsahu $12 \mathrm{H}_{2} \mathrm{O}$.

Tabulka 4 Chemické složení phillipsitu-Ca z Libé (hm. \%)

\begin{tabular}{lrrrrrrr}
\hline & mean & 1 & 2 & 3 & 4 & 5 & 6 \\
\hline $\mathrm{SiO}_{2}$ & 46.09 & 50.03 & 46.87 & 45.06 & 44.62 & 43.92 & 46.02 \\
$\mathrm{Al}_{2} \mathrm{O}_{3}$ & 22.87 & 22.54 & 22.39 & 23.17 & 23.17 & 22.87 & 23.08 \\
$\mathrm{CaO}$ & 7.77 & 7.55 & 7.69 & 7.99 & 7.71 & 7.77 & 7.88 \\
$\mathrm{BaO}$ & 0.73 & 0.89 & 0.68 & 0.72 & 0.72 & 0.74 & 0.63 \\
$\mathrm{Na}_{2} \mathrm{O}$ & 0.33 & 0.44 & 0.42 & 0.26 & 0.32 & 0.18 & 0.37 \\
$\mathrm{~K}_{2} \mathrm{O}$ & 4.71 & 4.95 & 5.25 & 5.09 & 4.65 & 4.54 & 3.78 \\
$\mathrm{H}_{2} \mathrm{O}^{*}$ & 16.25 & 17.07 & 16.37 & 16.13 & 15.97 & 15.74 & 16.22 \\
\hline total & 98.75 & 103.47 & 99.67 & 98.42 & 97.16 & 95.76 & 97.98 \\
\hline $\mathrm{Si}^{4+}$ & 10.204 & 10.543 & 10.303 & 10.052 & 10.053 & 10.042 & 10.205 \\
$\mathrm{Al}^{3+}$ & 5.966 & 5.599 & 5.800 & 6.091 & 6.152 & 6.163 & 6.033 \\
$\mathrm{Ca}^{2+}$ & 1.842 & 1.704 & 1.811 & 1.910 & 1.861 & 1.903 & 1.872 \\
$\mathrm{Ba}^{2+}$ & 0.064 & 0.058 & 0.058 & 0.063 & 0.064 & 0.066 & 0.055 \\
$\mathrm{Na}^{+}$ & 0.141 & 0.180 & 0.180 & 0.113 & 0.141 & 0.080 & 0.160 \\
$\mathrm{~K}^{+}$ & 1.330 & 1.329 & 1.471 & 1.448 & 1.338 & 1.324 & 1.068 \\
\hline$\Sigma \mathrm{Ca}+\mathrm{Ba}+\mathrm{Na}+\mathrm{K}$ & 3.377 & 3.271 & 3.520 & 3.534 & 3.404 & 3.373 & 3.155 \\
\hline $\mathrm{H}_{2} \mathrm{O}$ & 12 & 12 & 12 & 12 & 12 & 12 & 12 \\
$\mathrm{~T}_{\mathrm{Si}}$ & 0.63 & 0.65 & 0.64 & 0.62 & 0.62 & 0.62 & 0.63 \\
\hline $\mathrm{Em}$ & & & & & \\
\hline
\end{tabular}

Empirický vzorec byl přepočten na bázi 32 kyslíků, $\mathrm{H}_{2} \mathrm{O}^{*}$ bylo dopočíáno na základě teoretického obsahu $12 \mathrm{H}_{2} \mathrm{O}$. 
race $\mathrm{Sr}$ zjištěny u thomsonitu-Ca z Tachovského vrchu (0.38 apfu) (Pauliš et al. 2017) a z Babětína u Těchlovic (0.39 apfu) (Pauliš et al. 2018b). V zahraničí však byly zjištěny strontnaté thomsonity $s$ podstatně vyššími obsahy Sr. Nejvyšší obsahy Sr (5.68 apfu) má samostatně vyčleněný minerální druh thomsonit-Sr, který byl popsán $\mathrm{z}$ alkalického pegmatitu $\vee$ Chibinském masivu na Kolském poloostrově v Rusku (Pekov et al. 2001). Empirický vzorec thomsonitu-Ca (průměr osmi bodových analýz) je na bázi 20 kyslíkư možno vyjádřit jako $\mathrm{Ca}_{1.79} \mathrm{Sr}_{0.18} \mathrm{Na}_{1.05}\left(\mathrm{Al}_{4.81} \mathrm{Si}_{5.15}\right) \mathrm{O}_{20} \cdot 6 \mathrm{H}_{2} \mathrm{O}$. Hodnota $\mathrm{T}_{\mathrm{Si}}=\mathrm{Si} /$ $(\mathrm{Si}+\mathrm{Al})=0.52$ tohoto thomsonitu se nachází ve spodní části rozmezí uváděného pro tento zeolit $(0.50-0.56)$ (Coombs et al. 1997).

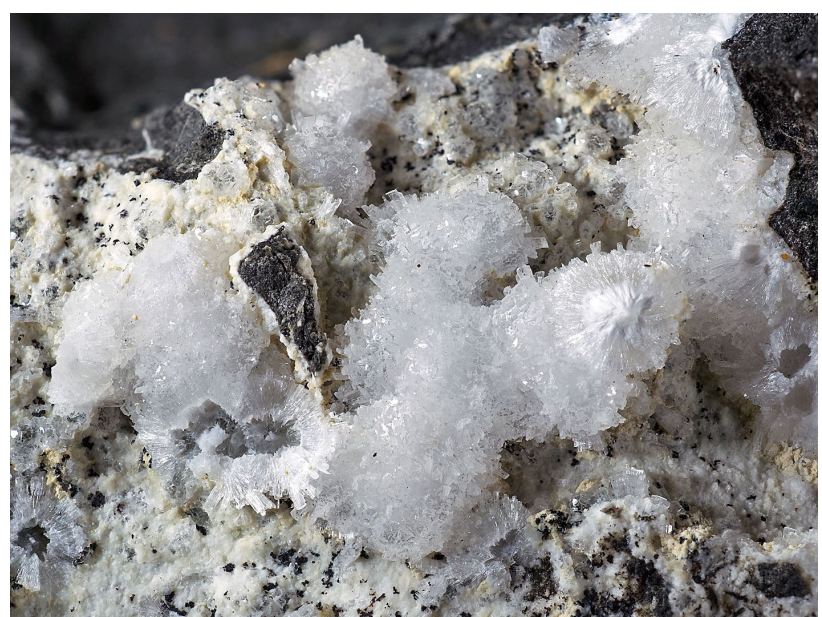

Obr. 5 Radiálně paprsčité agregáty thomsonitu-Ca z Libé, šiřka záběru $40 \mathrm{~mm}$, foto $P$. Fuchs.

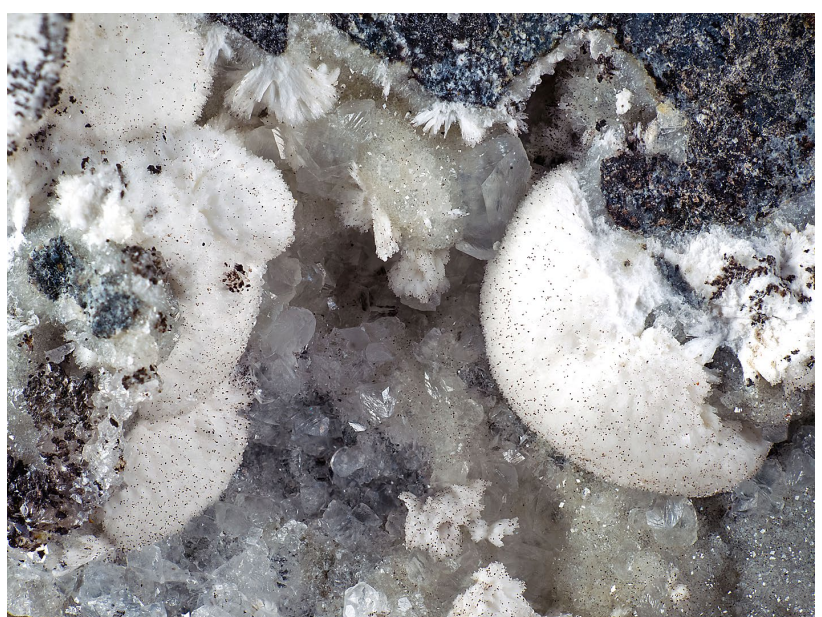

Obr. 6 Polokulovité agregáty natrolitu s drobnými krystaly kalcitu, narůstající na phillipsit z Libé, šírka záběru $20 \mathrm{~mm}$, foto P. Fuchs.

Tabulka 5 Rentgenová prášková data thomsonitu-Ca z Libé

\begin{tabular}{|c|c|c|c|c|c|c|c|c|c|c|c|c|c|c|c|c|c|}
\hline$h$ & $k$ & I & $d_{o b s}$ & $I_{o b s}$ & $d_{\text {calc }}$ & $h$ & $k$ & I & $d_{o b s}$ & $I_{o b s}$ & $d_{\text {calc }}$ & $h$ & $k$ & 1 & $d_{o b s}$ & $I_{o b s}$ & $d_{c a l c}$ \\
\hline 1 & 1 & 0 & 9.211 & 14 & 9.250 & 4 & 3 & 3 & 2.2531 & 7 & 2.2517 & 3 & 6 & 5 & 1.5696 & 1 & 1.5693 \\
\hline 2 & 0 & 0 & 6.583 & 16 & 6.553 & 0 & 5 & 3 & 2.2474 & 1 & 2.2477 & 0 & 6 & 6 & 1.5505 & $<1$ & 1.5498 \\
\hline 0 & 2 & 0 & 6.526 & 58 & 6.528 & 2 & 4 & 4 & 2.1903 & 5 & 2.1909 & 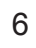 & 6 & 0 & 1.5413 & 1 & 1.5416 \\
\hline 1 & 0 & 2 & 5.887 & 10 & 5.911 & 4 & 4 & 2 & 2.1824 & 11 & 2.1832 & 3 & 1 & 8 & 1.5377 & 1 & 1.5376 \\
\hline 2 & 1 & 1 & 5.366 & 2 & 5.356 & 0 & 6 & 0 & 2.1746 & 45 & 2.1761 & 4 & 3 & 7 & 1.5342 & 1 & 1.5336 \\
\hline 0 & 2 & 2 & 4.638 & 27 & 4.649 & 3 & 5 & 2 & 2.1241 & 3 & 2.1231 & 5 & 7 & 0 & 1.5197 & $<1$ & 1.5197 \\
\hline 2 & 2 & 1 & 4.614 & 100 & 4.566 & 1 & 6 & 1 & 2.1208 & 4 & 2.1191 & 5 & 7 & 1 & 1.5097 & 1 & 1.5098 \\
\hline 1 & 3 & 0 & 4.128 & 45 & 4.130 & 1 & 2 & 6 & 2.0642 & 9 & 2.0653 & 3 & 2 & 8 & 1.5066 & 1 & 1.5065 \\
\hline 1 & 3 & 1 & 3.944 & 2 & 3.943 & 6 & 2 & 1 & 2.0465 & 1 & 2.0465 & 5 & 2 & r & 1.4933 & 1 & 1.4936 \\
\hline 2 & 2 & 2 & 3.783 & 1 & 3.792 & 1 & 5 & 4 & 2.0238 & 1 & 2.0259 & 5 & 7 & 2 & 1.4815 & 1 & 1.4812 \\
\hline 1 & 3 & 2 & 3.506 & 2 & 3.505 & 6 & 2 & 2 & 1.9752 & 2 & 1.9769 & 0 & 4 & 8 & 1.4770 & 1 & 1.4767 \\
\hline 3 & 2 & 1 & 3.501 & 25 & 3.501 & 3 & 0 & 6 & 1.9707 & 1 & 1.9704 & 1 & 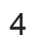 & 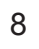 & 1.4674 & 3 & 1.4674 \\
\hline 4 & 0 & 0 & 3.277 & 5 & 3.276 & 2 & 5 & 4 & 1.9584 & 1 & 1.9570 & U & 8 & 4 & 1.4638 & 7 & 1.4640 \\
\hline 0 & 4 & 0 & 3.264 & 5 & 3.264 & 4 & 5 & 2 & 1.9502 & 3 & 1.9514 & 3 & 6 & 6 & 1.4606 & 6 & 1.4606 \\
\hline 2 & 2 & 3 & 3.200 & 7 & 3.194 & 2 & 6 & 3 & 1.8715 & 1 & 1.8707 & 7 & 4 & 4 & 1.4578 & 1 & 1.4581 \\
\hline 2 & 3 & 2 & 3.174 & 18 & 3.180 & 6 & 4 & 0 & 1.8148 & 8 & 1.8153 & 1 & 1 & 9 & 1.4538 & 1 & 1.4536 \\
\hline 1 & 4 & 1 & 3.079 & 4 & 3.081 & 1 & 4 & 6 & 1.8119 & 7 & 1.8112 & 9 & 1 & 0 & 1.4472 & 1 & 1.4472 \\
\hline 4 & 0 & 2 & 2.940 & 3 & 2.937 & 1 & 2 & 7 & 1.8003 & 3 & 1.8003 & 9 & 1 & 1 & 1.4387 & 1 & 1.4386 \\
\hline 2 & 4 & 0 & 2.918 & 24 & 2.922 & 4 & 6 & 1 & 1.7961 & 3 & 1.7960 & 5 & 7 & 3 & 1.4365 & $<1$ & 1.4370 \\
\hline 4 & 2 & 1 & 2.860 & 25 & 2.859 & 7 & 2 & 1 & 1.7835 & 1 & 1.7833 & 1 & 9 & 1 & 1.4338 & $<1$ & 1.4335 \\
\hline 2 & 4 & 1 & 2.853 & 39 & 2.853 & 1 & 7 & 2 & 1.7795 & 2 & 1.7788 & 4 & 8 & 2 & 1.4262 & 2 & 1.4266 \\
\hline 2 & 4 & 2 & 2.674 & 39 & 2.673 & 2 & 7 & 1 & 1.7777 & 1 & 1.7778 & 9 & 0 & 2 & 1.4223 & 2 & 1.4222 \\
\hline 4 & 1 & 3 & 2.5793 & 4 & 2.5793 & 7 & 3 & 0 & 1.7196 & 11 & 1.7198 & 5 & 5 & 6 & 1.4173 & 1 & 1.4180 \\
\hline 1 & 4 & 3 & 2.5754 & 2 & 2.5737 & 3 & 7 & 0 & 1.7153 & 2 & 1.7154 & 6 & 2 & 7 & 1.3968 & $<1$ & 1.3971 \\
\hline 4 & 3 & 1 & 2.5683 & 5 & 2.5679 & 2 & 3 & 7 & 1.6773 & 1 & 1.6776 & 0 & 3 & 9 & 1.3939 & $<1$ & 1.3943 \\
\hline 1 & 5 & 0 & 2.5593 & 6 & 2.5610 & 8 & 0 & 0 & 1.6372 & $<1$ & 1.6382 & 8 & 4 & 3 & 1.3897 & $<1$ & 1.3897 \\
\hline 5 & 1 & 1 & 2.5228 & $<1$ & 2.5228 & 0 & 8 & 0 & 1.6319 & 3 & 1.6321 & 6 & 7 & 2 & 1.3870 & 1 & 1.3870 \\
\hline 3 & 4 & 2 & 2.4294 & 9 & 2.4322 & 2 & 6 & 5 & 1.6282 & 1 & 1.6288 & 1 & 8 & 5 & 1.3816 & $<1$ & 1.3818 \\
\hline 2 & 5 & 1 & 2.3863 & 1 & 2.3861 & 5 & 6 & 2 & 1.6233 & 3 & 1.6232 & 8 & 5 & 1 & 1.3803 & 2 & 1.3802 \\
\hline 4 & 4 & 0 & 2.3108 & 3 & 2.3124 & 8 & 1 & 1 & 1.6135 & 4 & 1.6133 & 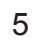 & 8 & 1 & 1.3777 & $<1$ & 1.3779 \\
\hline 1 & 4 & 4 & 2.2901 & 1 & 2.2890 & 8 & 2 & 0 & 1.5885 & 2 & 1.5889 & 6 & 3 & 7 & 1.3585 & $<1$ & 1.3588 \\
\hline 5 & 2 & 2 & 2.2814 & 2 & 2.2833 & 0 & 8 & 2 & 1.5844 & 2 & 1.5847 & 5 & 8 & 2 & 1.3556 & $<1$ & 1.3561 \\
\hline 4 & 4 & 1 & 2.2763 & $<1$ & 2.2780 & 1 & 8 & 2 & 1.5731 & 3 & 1.5732 & 9 & 3 & 2 & 1.3516 & $<1$ & 1.3518 \\
\hline
\end{tabular}




\section{Natrolit}

Poměrně hojným minerálem lokality je natrolit, který byl nalezen v jižní i jihozápadní části kamenolomu. $\mathrm{Na}$ puklinách a $v$ plochých dutinách nefelinitu vytváří většinou polokulovité jehličkovité až ježkovité, radiálně paprsčité agregáty sněhově bílé barvy (obr. 6,7). Jednotlivé jehličkovité krystaly mají čiré zakončení. Na lokalitě však byly zjištěny i vějiřrovité agregáty čirého natrolitu, který srůstá s podobným gonnarditem. Povrch sférických agregátů natrolitu je často zbarven povlaky jílových minerálů do světlé žluté, žlutozelené až šedozelené barvy nebo jsou natrolitové polokoule pokryté černohnědými vyloučeninami oxidů $\mathrm{Fe}$ a Mn. Velikost kulovitých a ježkovitých agregátů dosahuje běžně $5 \mathrm{~mm}$, vzácněji $1 \mathrm{~cm}$. V drobných dutinách vytváří tento minerál samostatné čiré sloupečkovité krystaly nebo jejich skupiny o velikosti kolem 1 $\mathrm{mm}$. Natrolit ve většině př́ipadů narůstá na drobně krystalované kůry phillipsitu. Nalezeny byly i bílé kulovité agregáty natrolitu uzavřené v šedozeleném jílovém minerálu.

Rentgenová prášková data natrolitu z Libé (tab. 8) jsou blízká datům pro tento minerální druh, zpresněné parametry jeho základní cely jsou v tabulce 9 porovnány s publikovanými daty pro tento zeolit.

V BSE obraze je studovaný minerál chemicky homogenní. Při studiu jeho chemického složení (tab. 10) byly zjištěny obsahy $\mathrm{Si}, \mathrm{Al}, \mathrm{Ca}$ a Na; ostatní měřené prvky byly pod mezí detekce. Vedle dominantního obsahu Na obsahuje tento natrolit malou príměs $\mathrm{Ca}(0.05 \mathrm{apfu})$. Empirický vzorec natrolitu z Libé (průměr pěti bodových analýz) je na bázi 10 kyslíků možno vyjádřit jako $\mathrm{Na}_{1.60} \mathrm{Ca}_{0.05}\left(\mathrm{Al}_{2.08}\right.$
$\left.\mathrm{Si}_{3.02}\right) \mathrm{O}_{10} \cdot 2 \mathrm{H}_{2} \mathrm{O}$. Hodnota $\mathrm{T}_{\mathrm{Si}}=\mathrm{Si} /(\mathrm{Si}+\mathrm{Al})=0.59$ tohoto natrolitu se nachází prí spodní hranici publikovaného rozmezí (0.59 - 0.62) (Coombs et al. 1997).

\section{Gonnardit}

$S$ čirým natrolitem $v$ některých agregátech srůstá vzhledově podobný gonnardit. $V$ dutinách nefelinitu, až $10 \mathrm{~cm}$ velkých, tvoři většinou čiré či bílé shluky plochých jehlicovitých krystalů o velikosti do $2 \mathrm{~mm}$, které vytvářejí vějírovitě uspořádané agregáty, narůstající na podklad krystalovaného phillipsitu (obr. 8).

Rentgenová prášková data gonnarditu z Libé (tab. 11) jsou blízká datům pro tento minerální druh, zpřesněné parametry jeho základní cely dobře odpovídají publikovaným údajům (tab. 12).

V BSE obraze je studovaný minerál chemicky homogenní. Při studiu jeho chemického složení (tab. 13) byly zjištěny obsahy $\mathrm{Si}, \mathrm{Al}, \mathrm{Ca}, \mathrm{Sr}$ a Na; ostatní měřené prvky byly pod mezí detekce. Vedle $\mathrm{Na}$ (3.14 apfu) a Ca (2.21 apfu) obsahuje tento natrolit malou príměs $\mathrm{Sr}$ (0.02 apfu). Empirický vzorec gonnarditu z Libé (průměr čtyř bodových analýz) je na bázi 40 kyslíků možno vyjádřit jako $\left(\mathrm{Na}_{3.14} \mathrm{Ca}_{2.21} \mathrm{Sr}_{0.02}\right)_{\Sigma 5.37}\left(\mathrm{Al}_{8.92} \mathrm{Si}_{11.41}\right)_{\Sigma 20.33} \mathrm{O}_{40} \cdot 12 \mathrm{H}_{2} \mathrm{O}$. Hodnota $\mathrm{T}_{\mathrm{Si}}=\mathrm{Si} /(\mathrm{Si}+\mathrm{Al})=0.56$ tohoto gonnarditu se nachází ve střední části rozmezí uváděného pro tento zeolit (0.520.59) (Coombs et al. 1997).

Kromě zeolitů byly na této lokalitě nalezeny další minerály. Jde o kalcit, který je vedle jílového minerálu nejmladším minerálem popsané asociace. Nejčastěji zcela vyplňuje drobné dutiny se zeolity $v$ nefelinitu. Ve větších dutinách ojediněle tvoří mléčně bílé, až $1 \mathrm{~cm}$ velké, níz-

Tabulka 6 Parametry základní cely thomsonitu-Ca (pro ortorombickou prostorovou grupu Pncn)

\begin{tabular}{llllll}
\hline & & $a[\AA]$ & $b[\AA]$ & $c[\AA]$ & $V\left[\AA^{3}\right]$ \\
\hline Libá & tato práce & $13.105(5)$ & $13.857(5)$ & $13.247(6)$ & $2266.7(6)$ \\
& Stahl et al. (1990) & $13.1043(14)$ & $13.0569(18)$ & $13.2463(30)$ & 2266.46 \\
Tachov & Pauliš et al. (2017) & $13.1081(14)$ & $13.0558(18)$ & $13.2448(16)$ & $2266.7(5)$ \\
Jehla & Pauliš et al. (2015) & $13.104(2)$ & $13.056(1)$ & $13.247(2)$ & $2266.4(6)$ \\
Babětín & Pauliš et al. (2018b) & $13.1049(12)$ & $13.0559(13)$ & $13.2464(12)$ & $2266.4(4)$ \\
Heřmanice & Pauliš et al. (2018a) & $13.104(2)$ & $13.0570(19)$ & $13.245(3)$ & $2266.2(6)$ \\
Hackenberg & Pauliš et al. (2014) & $13.104(2)$ & $13.056(1)$ & $13.247(2)$ & $2266.4(6)$ \\
\hline
\end{tabular}

Tabulka 7 Chemické složení thomsonitu-Ca z Libé (hm. \%)

\begin{tabular}{lrrrrrrrrr}
\hline & mean & 1 & 2 & 3 & 4 & 5 & 6 & 7 & 8 \\
\hline $\mathrm{SiO}_{2}$ & 36.40 & 36.41 & 36.07 & 35.61 & 37.09 & 37.45 & 35.88 & 36.38 & 36.31 \\
$\mathrm{Al}_{2} \mathrm{O}_{3}$ & 28.89 & 29.52 & 28.95 & 29.33 & 28.73 & 28.54 & 28.37 & 28.12 & 29.57 \\
$\mathrm{CaO}$ & 11.84 & 11.79 & 11.91 & 11.77 & 11.92 & 12.07 & 11.79 & 11.70 & 11.78 \\
$\mathrm{SrO}$ & 2.18 & 2.36 & 2.36 & 2.66 & 1.05 & 1.08 & 2.71 & 2.68 & 2.52 \\
$\mathrm{Na}_{2} \mathrm{O}$ & 3.74 & 3.62 & 3.58 & 3.75 & 3.85 & 3.95 & 3.68 & 3.61 & 3.84 \\
$\mathrm{H}_{2} \mathrm{O}^{*}$ & 12.72 & 12.82 & 12.68 & 12.68 & 12.67 & 12.84 & 12.56 & 12.59 & 12.84 \\
\hline total & 95.77 & 96.52 & 95.55 & 95.80 & 95.31 & 95.93 & 94.99 & 95.08 & 96.86 \\
\hline $\mathrm{Si}^{4+}$ & 5.146 & 5.110 & 5.118 & 5.054 & 5.266 & 5.247 & 5.136 & 5.196 & 5.089 \\
$\mathrm{Al}^{3+}$ & 4.814 & 4.882 & 4.891 & 4.906 & 4.807 & 4.712 & 4.786 & 4.734 & 4.884 \\
$\mathrm{Ca}^{2+}$ & 1.793 & 1.772 & 1.815 & 1.790 & 1.813 & 1.811 & 1.808 & 1.790 & 1.769 \\
$\mathrm{Sr}^{2+}$ & 0.178 & 0.192 & 0.194 & 0.228 & 0.086 & 0.088 & 0.225 & 0.222 & 0.205 \\
$\mathrm{Na}^{+}$ & 1.025 & 0.985 & 0.986 & 1.032 & 1.059 & 1.072 & 1.022 & 0.999 & 1.043 \\
\hline$\Sigma \mathrm{Ca}+\mathrm{Sr}+\mathrm{Na}$ & 2.996 & 2.949 & 2.995 & 3.050 & 2.958 & 2.971 & 3.055 & 3.011 & 3.017 \\
\hline $\mathrm{H}_{2} \mathrm{O}$ & 6 & 6 & 6 & 6 & 6 & 6 & 6 & 6 & 6 \\
$\mathrm{~T}_{\mathrm{Si}}$ & 0.52 & 0.51 & 0.51 & 0.51 & 0.52 & 0.53 & 0.52 & 0.52 & 0.51 \\
\hline
\end{tabular}

Empirický vzorec byl přepočten na bázi 20 kyslíků, $\mathrm{H}_{2} \mathrm{O}^{*}$ bylo dopočítáno na základě teoretického obsahu $6 \mathrm{H}_{2} \mathrm{O}$. 
Tabulka 8 Rentgenová prášková data natrolitu z Libé

\begin{tabular}{rrrrrrrrrrrrrrrrrr}
\hline$h$ & $k$ & $l$ & $d_{o b s}$ & $I_{\text {obs }}$ & $d_{\text {calc }}$ & $h$ & $k$ & $l$ & $d_{o b s}$ & $l_{\text {obs }}$ & $d_{\text {calc }}$ & $h$ & $k$ & $l$ & $d_{o b s}$ & $l_{\text {obs }}$ & $d_{c a l c}$ \\
\hline 2 & 2 & 0 & 6.496 & 100 & 6.522 & 5 & 3 & 1 & 2.840 & 4 & 2.845 & 8 & 4 & 2 & 1.7427 & 2 & 1.7435 \\
1 & 1 & 1 & 5.884 & 14 & 5.884 & 4 & 6 & 0 & 2.5643 & $<1$ & 2.5646 & 4 & 10 & 0 & 1.7224 & 1 & 1.7209 \\
0 & 4 & 0 & 4.627 & 6 & 4.642 & 1 & 7 & 1 & 2.4401 & 1 & 2.4391 & 10 & 4 & 0 & 1.7033 & $<1$ & 1.7046 \\
4 & 0 & 0 & 4.570 & 3 & 4.581 & 7 & 1 & 1 & 2.4106 & 1 & 2.4126 & 0 & 0 & 4 & 1.6491 & 1 & 1.6484 \\
1 & 3 & 1 & 4.405 & 12 & 4.382 & 4 & 4 & 2 & 2.3145 & 1 & 2.3184 & 8 & 8 & 0 & 1.6316 & 1 & 1.6304 \\
3 & 1 & 1 & 4.343 & 2 & 4.356 & 3 & 7 & 1 & 2.2782 & 2 & 2.2827 & 6 & 8 & 2 & 1.6129 & 1 & 1.6120 \\
2 & 4 & 0 & 4.138 & 8 & 4.141 & 7 & 3 & 1 & 2.2717 & 5 & 2.2645 & 10 & 0 & 2 & 1.6022 & 2 & 1.6017 \\
4 & 2 & 0 & 4.102 & 4 & 4.108 & 6 & 6 & 0 & 2.1733 & 1 & 2.1739 & 7 & 9 & 1 & 1.5726 & $<1$ & 1.5737 \\
4 & 4 & 0 & 3.256 & $<1$ & 3.261 & 1 & 3 & 3 & 2.0566 & $<1$ & 2.0581 & 0 & 12 & 0 & 1.5452 & $<1$ & 1.5474 \\
1 & 5 & 1 & 3.184 & 3 & 3.187 & 1 & 9 & 1 & 1.9582 & $<1$ & 1.9578 & 10 & 4 & 2 & 1.5138 & $<1$ & 1.5142 \\
5 & 1 & 1 & 3.151 & 2 & 3.157 & 1 & 5 & 3 & 1.8803 & 1 & 1.8815 & 11 & 5 & 1 & 1.4828 & $<1$ & 1.4812 \\
0 & 2 & 2 & 3.103 & 2 & 3.107 & 8 & 2 & 2 & 1.8453 & 2 & 1.8437 & 4 & 12 & 0 & 1.4667 & $<1$ & 1.4661 \\
2 & 2 & 2 & 2.949 & 4 & 2.942 & 8 & 6 & 0 & 1.8410 & 2 & 1.8412 & 10 & 8 & 0 & 1.4389 & $<1$ & 1.4383 \\
6 & 2 & 0 & 2.893 & 31 & 2.901 & 2 & 10 & 0 & 1.8230 & 1 & 1.8199 & 2 & 6 & 4 & 1.4372 & 1 & 1.4369 \\
3 & 5 & 1 & 2.857 & 5 & 2.859 & 7 & 7 & 1 & 1.7940 & 1 & 1.7931 & 9 & 9 & 1 & 1.4158 & $<1$ & 1.4155 \\
\hline
\end{tabular}

Tabulka 9 Parametry základní cely natrolitu (pro ortorombickou prostorovou grupu Fdd2)

\begin{tabular}{ccccc}
\hline & tato práce & Alberti et al. (1995) & Jehla (Pauliš et al. 2015) & Babětín (Pauliš et al. 2018b) \\
\hline$a[\AA]$ & $18.326(7)$ & $18.3469(70)$ & $18.376(5)$ & $18.338(10)$ \\
$b[\AA]$ & $18.569(7)$ & $18.5610(40)$ & $18.552(5)$ & $18.565(9)$ \\
$c[\AA]$ & $6.594(3)$ & $6.587(4)$ & $6.585(2)$ & $6.587(4)$ \\
$V\left[\AA^{3}\right]$ & $2243.8(9)$ & 2243.12 & $2244(1)$ & $2241(1)$ \\
\hline
\end{tabular}

Tabulka 10 Chemické složení natrolitu z Libé (hm. \%)

\begin{tabular}{lrrrrrr}
\hline & mean & 1 & 2 & 3 & 4 & 5 \\
\hline $\mathrm{SiO}_{2}$ & 48.07 & 48.02 & 48.38 & 47.84 & 48.48 & 47.61 \\
$\mathrm{Al}_{2} \mathrm{O}_{3}$ & 28.05 & 28.53 & 28.00 & 28.25 & 27.28 & 28.17 \\
$\mathrm{CaO}$ & 0.70 & 0.87 & 0.73 & 0.70 & 0.59 & 0.60 \\
$\mathrm{Na}_{2} \mathrm{O}$ & 13.18 & 13.00 & 12.62 & 13.41 & 13.53 & 13.33 \\
$\mathrm{H}_{2} \mathrm{O}$ & 9.55 & 9.59 & 9.55 & 9.56 & 9.53 & 9.51 \\
\hline total & 99.55 & 100.01 & 99.28 & 99.76 & 99.41 & 99.22 \\
\hline $\mathrm{Si}^{4+}$ & 3.017 & 3.001 & 3.037 & 3.001 & 3.050 & 3.002 \\
$\mathrm{Al}^{3+}$ & 2.075 & 2.101 & 2.072 & 2.089 & 2.023 & 2.073 \\
$\mathrm{Ca}^{2+}$ & 0.047 & 0.058 & 0.049 & 0.047 & 0.040 & 0.041 \\
$\mathrm{Na}^{+}$ & 1.603 & 1.575 & 1.536 & 1.631 & 1.650 & 1.630 \\
\hline $\mathrm{H}_{2} \mathrm{O}$ & 2 & 2 & 2 & 2 & 2 & 2 \\
$\mathrm{~T}_{\mathrm{Si}}$ & 0.59 & 0.59 & 0.59 & 0.59 & 0.60 & 0.59 \\
\hline
\end{tabular}

Empirický vzorec byl přepočten na bázi 10 kyslíků, $\mathrm{H}_{2} \mathrm{O}$ bylo dopočítáno na základě teoretického obsahu $2 \mathrm{H}_{2} \mathrm{O}$.

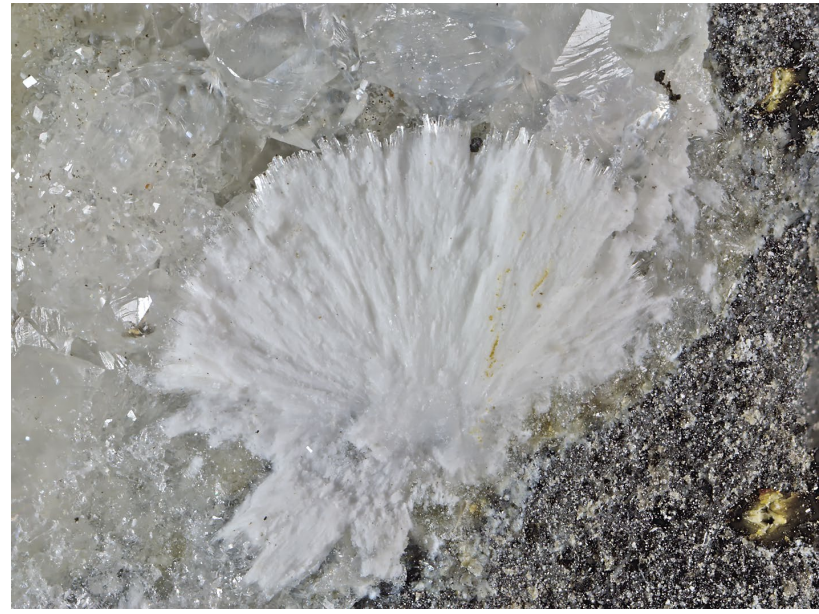

Obr. 7 Radiálně paprsčitý agregát natrolitu s kalcitem a phillipsitem z Libé, šiřka záběru $8 \mathrm{~mm}$, foto B. Bureš.

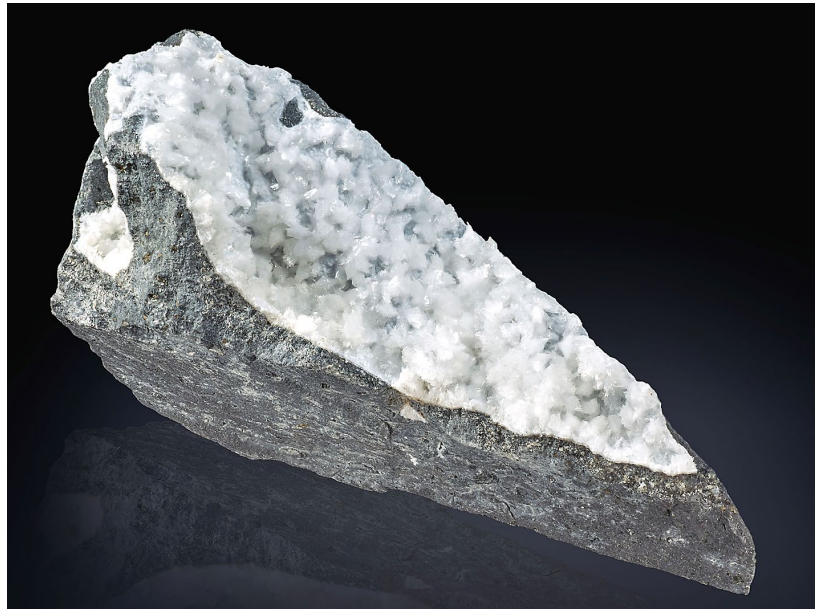

Obr. 8 Dutina $v$ bazaltu vyplněná krystaly gonnarditu s natrolitem z Libé, velikost vzorku $9 \times 3 \mathrm{~cm}$, foto P. Fuchs. 
Tabulka 11 Rentgenová prášková data gonnarditu z Libé

\begin{tabular}{cccccccccccccccccc}
\hline$h$ & $k$ & $l$ & $d_{o b s}$ & $l_{\text {obs }}$ & $d_{\text {calc }}$ & $h$ & $k$ & $l$ & $d_{o b s}$ & $l_{\text {obs }}$ & $d_{\text {calc }}$ & $h$ & $k$ & $l$ & $d_{o b s}$ & $l_{\text {obs }}$ & $d_{\text {calc }}$ \\
\hline 0 & 2 & 0 & 6.605 & 100 & 6.610 & 4 & 0 & 2 & 2.3437 & 6 & 2.3392 & 3 & 7 & 0 & 1.7419 & 11 & 1.7359 \\
1 & 0 & 1 & 5.886 & 27 & 5.921 & 2 & 5 & 1 & 2.3048 & 3 & 2.3019 & 4 & 3 & 3 & 1.6919 & 1 & 1.6945 \\
2 & 2 & 0 & 4.684 & 93 & 4.674 & 3 & 5 & 0 & 2.2664 & 4 & 2.2673 & 5 & 2 & 3 & 1.6442 & 5 & 1.6414 \\
2 & 1 & 1 & 4.400 & 34 & 4.410 & 2 & 4 & 2 & 2.2041 & 15 & 2.2052 & 5 & 5 & 2 & 1.6299 & 3 & 1.6280 \\
3 & 1 & 0 & 4.190 & 39 & 4.181 & 1 & 0 & 3 & 2.1707 & 1 & 2.1772 & 2 & 0 & 4 & 1.6069 & 3 & 1.6059 \\
3 & 0 & 1 & 3.674 & 1 & 3.669 & 6 & 2 & 0 & 2.0989 & 2 & 2.0903 & 1 & 6 & 3 & 1.5471 & 1 & 1.5487 \\
0 & 4 & 0 & 3.314 & 5 & 3.305 & 6 & 1 & 1 & 2.0631 & 1 & 2.0651 & 7 & 3 & 2 & 1.5374 & 1 & 1.5374 \\
3 & 2 & 1 & 3.206 & 29 & 3.208 & 5 & 1 & 2 & 2.0391 & $<1$ & 2.0414 & 5 & 4 & 3 & 1.5072 & $<1$ & 1.5079 \\
1 & 1 & 2 & 3.109 & 6 & 3.121 & 5 & 4 & 1 & 1.9710 & 2 & 1.9711 & 0 & 4 & 4 & 1.4812 & 6 & 1.4802 \\
2 & 0 & 2 & 2.964 & 14 & 2.960 & 3 & 6 & 1 & 1.8881 & 2 & 1.8889 & 3 & 6 & 3 & 1.4682 & 1 & 1.4701 \\
2 & 4 & 0 & 2.950 & 17 & 2.956 & 5 & 3 & 2 & 1.8733 & 1 & 1.8707 & 8 & 2 & 2 & 1.4395 & 2 & 1.4430 \\
4 & 1 & 1 & 2.888 & 86 & 2.886 & 1 & 4 & 3 & 1.8216 & 5 & 1.8182 & 7 & 6 & 1 & 1.3989 & 1 & 1.4015 \\
1 & 3 & 2 & 2.603 & 13 & 2.596 & 2 & 6 & 2 & 1.7703 & 1 & 1.7676 & 4 & 8 & 2 & 1.3498 & $<1$ & 1.3497 \\
4 & 3 & 1 & 2.4603 & 15 & 2.4556 & & & & & & & & & & & \\
\hline
\end{tabular}

Tabulka 12 Parametry základní cely gonnarditu (pro ortorombickou prostorovou grupu l-42d)

\begin{tabular}{rcc} 
& tato práce & Artioli, Torres Salvador (1991) \\
\hline$a[\AA]$ & $13.221(8)$ & $13.2163(3)$ \\
$c[\AA]$ & $6.6222(6)$ & $6.6233(4)$ \\
$V\left[\AA^{3}\right]$ & $1157.4(8)$ & 1156.9 \\
\hline
\end{tabular}

Tabulka13 Chemické složení gonnarditu z Libé (hm. \%)

\begin{tabular}{lrrrrr}
\hline & mean & 1 & 2 & 3 & 4 \\
\hline $\mathrm{SiO}_{2}$ & 42.99 & 42.13 & 43.51 & 43.01 & 43.32 \\
$\mathrm{Al}_{2} \mathrm{O}_{3}$ & 28.52 & 28.35 & 28.20 & 28.89 & 28.62 \\
$\mathrm{CaO}$ & 7.77 & 7.43 & 5.50 & 8.89 & 9.26 \\
$\mathrm{SrO}$ & 0.24 & 0.18 & 0.26 & 0.32 & 0.19 \\
$\mathrm{Na}_{2} \mathrm{O}$ & 6.11 & 6.33 & 7.38 & 5.46 & 5.28 \\
$\mathrm{H}_{2} \mathrm{O}$ & 13.56 & 13.36 & 13.49 & 13.67 & 13.70 \\
\hline total & 99.19 & 97.78 & 98.34 & 100.24 & 100.37 \\
\hline $\mathrm{Si}^{4+}$ & 11.406 & 11.345 & 11.602 & 11.316 & 11.374 \\
$\mathrm{Al}^{3+}$ & 8.918 & 8.999 & 8.864 & 8.957 & 8.856 \\
$\mathrm{Ca}^{2+}$ & 2.210 & 2.144 & 1.572 & 2.506 & 2.604 \\
$\mathrm{Sr}^{2+}$ & 0.024 & 0.018 & 0.026 & 0.032 & 0.019 \\
$\mathrm{Na}^{+}$ & 3.144 & 3.304 & 3.816 & 12 & 2.786 \\
\hline $\mathrm{H}_{2} \mathrm{O}$ & 12 & 12 & 0.57 & 0.56 & 12 \\
$\mathrm{~T}_{\mathrm{Si}}$ & 0.56 & 0.56 & 12 & 0.56 \\
\hline
\end{tabular}

Empirický vzorec byl přepočten na bázi 40 kyslíků, $\mathrm{H}_{2} \mathrm{O}$ bylo dopočítáno na základě teoretického obsahu $12 \mathrm{H}_{2} \mathrm{O}$.

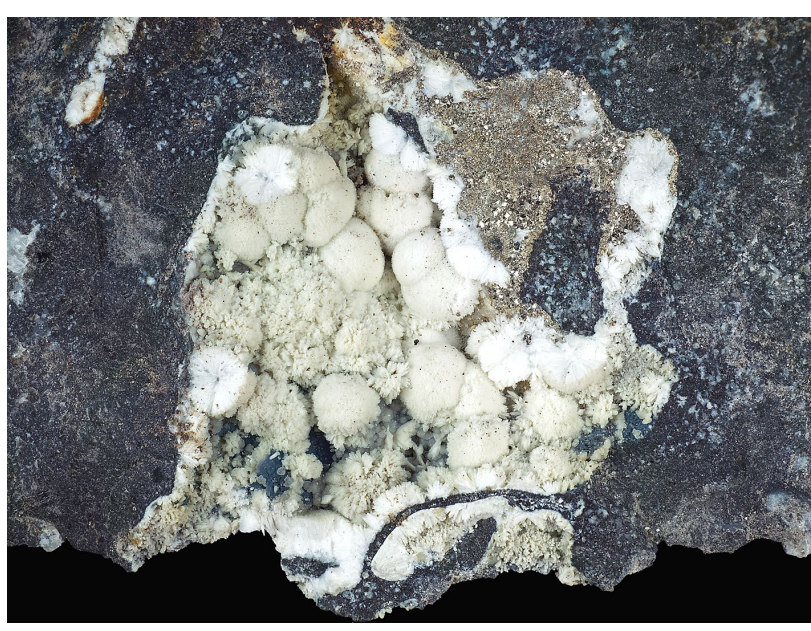

Obr. 9 Radiálně paprsčité agregáty natrolitu s pyritem z Libé, šírka záběru $30 \mathrm{~mm}$, foto P. Fuchs.

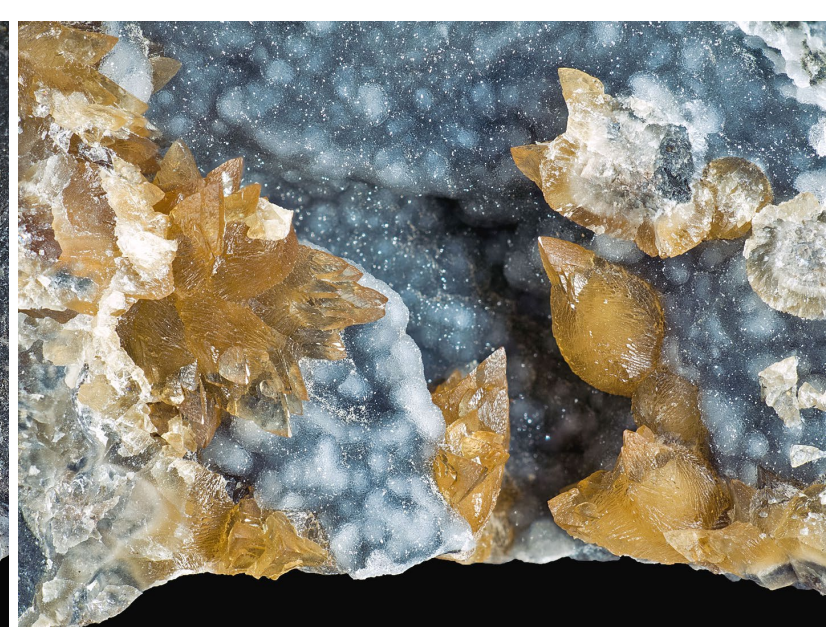

Obr. 10 Skalenoedrické krystaly kalcitu narostlé na phillipsitu z Libé, šírka záběru $20 \mathrm{~mm}$, foto P. Fuchs. 
ce klencové, často korodované krystaly, nebo žlutohnědé srůsty skalenoedrických krystalů (obr. 10) narůstajících na phillipsit. Místy je hojnější pyrit, který tvoří akumulace drobných, zlatožlutých, kovově lesklých zrn v hornině. Na puklinách pak vytváří jemně zrnité povlaky přecházející vzácně do drúzovité kưry s drobnými $(0.1 \mathrm{~mm})$ krychlovými, silně lesklými krystaly (obr. 9). Poslední součástí výplní dutin a puklin v bazaltech je blíže neidentifikovaný žlutavý jílový minerál, tvořící tenké povlaky na minerální výplni dutin či zcela vyplňující některé drobnější dutiny.

\section{Závěr}

V činném kamenolomu založeném v terciérním výlevu olivinického nefelinitu byla nově zjištěna zeolitová mineralizace s phillipsitem-K, phillipsitem-Ca, thomsonitem-Ca, natrolitem a gonnarditem. Spolu s nimi se v puklinách a dutinách nefelinitu vyskytují kalcit, pyrit a jílový minerál. Thomsonit obsahuje zvýšený podíl Sr (0.18 apfu). Lokalita je i nadále perspektivním výskytem zeolitové mineralizace; do budoucna nelze vyloučit nálezy dalších druhů, zvláště z natrolitové skupiny.

\section{Poděkování}

Milou povinností autorů je poděkovat za fotografie minerálů $P$. Fuchsovi a $B$. Burešovi. Dále autoři děkují jednateli společnosti Basalt CZ s.r.o. Ing. L. Boučkovi Ph.D. za poskytnuté materiály. Předložená práce vznikla za finanční podpory Ministerstva kultury $C \check{R} v$ rámci institucionálního financování dlouhodobého koncepčního rozvoje výzkumné organizace Národní muzeum (DKRVO 2019-2023/1.I.b, 00023272).

\section{Literatura}

Alberti A, Cruciani G, Dauru I (1995) Order-disorder in natrolite-group minerals. Eur J Mineral 7: 501-508

Artioli G, Torres Salvador MR (1991) Characterization of the natural zeolite gonnardite. Structure analysis of natural and cation exchanged species by the Rietveld method. Materials Science Forum 1156.1

Coombs DS, Alberti A, Armbruster T, Artioli G, Colella C, Galli E, Grice JD, Liebau F, Mandarino Ja, Minato H, Nickel EH, Passaglia E, Peacor DR, Quartieri S, Rinaldi R, Ross M, Sheppard RA, Tillmanns E, VezzalinI G (1997) Recommended nomenclature for zeolite minerals: report of the subcommittee on zeolites of the International Mineralogical Association, commission on new minerals and mineral names. Can Mineral 35: 1571-1606

ČTYŘokÝ V, KouBEK M (1959) Průzkum čediče 1957 - 1959 - Libá u Hazlova. MS archiv ČGS-Geofond Praha GF FZ003005

Gatta GD, Cappelletti P, Rotiroti N, Slebodnick C, Rinaldi $R$ (2009) New insights into the crystal structure and crystal chemistry of the zeolite phillipsite. Am Mineral 94: 190-199

HRZINA P, Koroš I, KRUTSKÝ J (2016) Libá, geologický průzkum (č. ložiska 3 019900), závěrečná zpráva s výpočtem zásob. MS archiv ČGS-Geofond Praha GF FZ007249
LAUgier J, Bochu B (2011) LMGP-Suite of Programs for the Interpretation of X-ray Experiments. http://www. ccp14.ac.uk/tutorial//mgp. prístup duben 2011

KRATOCHVIL J (1961) Topografická mineralogie Čech IV. NČSAV Praha

KRUTSKÝ J (2019) Geologická dokumentace hornické činnosti na výhradním ložisku Libá (B3 019 000) v DB Libá, Libá I a Libá II za rok 2018 těženého organizací BAZALT CZ s.r.o. MS GET Praha

Pauliš P, SVejkovský J, JaneČek O, Hrưzek L, DVoŘák Z, JebaVÁ I (2013) Offretit z kamenolomu Vrbička u Valče $\checkmark$ Doupovských horách. Bull mineral-petrolog Odd Nár Muz 21, 2: 171-178

Pauliš P, Hrůzek L, Janeček O, Sejkora J, Malíková R (2014) Cowlesit a doprovodná mineralizace z vrchu Hackenberg u České Kamenice (Česká republika). Bull mineral-petrolog Odd Nár Muz (Praha) 22, 2: 248-260

Pauliš P, Hrưzek L, Janeček O, Sejkora J, Malíková R, Pour O, FEDIuk F (2015) Tschernichit, garronit-Ca a doprovodná zeolitová mineralizace z Jehly u České Kamenice (Česká republika). Bull mineral-petrolog Odd Nár Muz (Praha) 23, 2: 147-170

Pauliš $P$, Hrưzek L, Janeček $O$, Sejkora J, Malíková R, FeDIUK F (2016a): Zeolitová mineralizace z Nového Oldřichova u Kamenického Šenova (Česká republika). Bull mineral-petrolog Odd Nár Muz (Praha) 24, 1: 100-113

Pauliš P, Hrůzek L, Janeček O, Sejkora J, Malíková R, Pour O, FEdIuk F (2016b) Zeolitová mineralizace ze Svoru u Nového Boru (Česká republika). Bull mineral -petrolog Odd Nár Muz (Praha) 24, 2: 194-204

Pauliš P, Janeček O, Hrưzek L, Sejkora J, Malíková R, Fediuk F, Pour O (2017) Nordstrandit a zeolitová mineralizace fonolitu Tachovského vrchu u Doks (Česká republika). Bull Mineral Petrolog 25, 1: 69-84

Pauliš P, Zeman P, Zeman V, Sejkora J, Malíková R, VRtiška L, Dolníček Z, Fediuk F, Pour O, Radoñ M (2018a): Zeolitová mineralizace z Heřmanic u České Lípy (Česká republika). Bull Mineral Petrolog 26, 2: 123-137

Pauliš P, Zeman P, Zeman J, Sejkora J, Malíková R, VRtišKa L, Dolní̌ek Z, Fediuk F, Pour O, RAdoñ M (2018b) Zeolitová mineralizace $s$ thomsonitem-Ca z Babětína u Těchlovic v Českém středohoří (Česká republika). Bull Mineral Petrolog 26, 1: 1-11

Pauliš P, Hrưzek L, Sejkora J, Dolniček Z, VRtiška L, MaLíková R, EKRT B, Pour O, FEDIUK F, JANEČEK O (2019) Zeolitová mineralizace ze Zaječího vrchu a Poustevny u Nového Boru. Bull Mineral Petrolog 27, 2: 346-369

Pekov IV, Turchkova AG, Chukanov NV, Zadov AE, Grichin VG (2000) Chabazite-Sr, $(\mathrm{Sr}, \mathrm{Ca})\left[\mathrm{Al}_{2} \mathrm{Si}_{4} \mathrm{O}_{12}\right] \cdot 6 \mathrm{H}_{2} \mathrm{O}$, a new zeolite mineral from Lovozero massif, Kola Peninsula. Zap Vseross mineral Obšč 129, 4: 54-58

Pouchou JL, PICHOIR F (1985) "PAP" ( $\varphi \rho Z)$ procedure for improved quantitative microanalysis. In: Microbeam Analysis (J. T. Armstrong, ed.). San Francisco Press, San Francisco, 104-106

StAHL K, KVICK A, Smith JV (1990) Thomsonite, a neutron diffraction study at $13 \mathrm{~K}$. Acta Crystallogr C 46: 13701373 